\title{
Application of Environmental Management Systems (EMS) to Natural Parks and reserves
}

\author{
F. Ardente, G. Beccali, M. Cellura \& M. Fontana \\ DREAM (Dipartimento di Ricerche Energetiche ed AMbientali), \\ Università degli Studi di Palermo, Italy
}

\begin{abstract}
Natural parks and reserves have to face problems concerning the conservation of their natural resources. Citizens and firms often perceive the institution of new protected areas more as a bind or a restriction to their activities than an added value of the territory. Following the principles of sustainable development, it is necessary to integrate the environmental protection with the needs of neighbouring urban areas and production sites. The implementation of an Environmental Management System (EMS) according to international standards (ISO 14001, EMAS) can support the Park administration in their complex management activities.

This paper analysed the criticisms related to the application of EMS to parks, with particular regards to the main difficulties during the certification process and the benefits and drawbacks related to the environmental certification. Keywords: Environmental Management System (EMS), Natural Parks.
\end{abstract}

\section{Introduction}

Natural Parks represent an "atypical" company characterized by various and complex functions and aims, mainly related to:

- the saving, protection and management of natural resources;

- the offer of cultural and social services promoting scientific, educational and recreational activities addressed to different users.

It is then essential that the park's management will correctly define and apply adequate procedures to monitor and control the "state of health" of its territory, making it transparent to the citizens. 
The introduction of an Environmental Managements System (EMS) to natural parks represents an engagement to grant a correct and sustainable fruition of the natural heritages. An EMS is defined as "the part of the overall management system that includes the organisational structure, planning activities, responsibilities, practices, procedures, processes and resources for developing, implementing, achieving, reviewing and maintaining the environmental policy" [EU, 2001]. EMSs have been regulated by the international standard ISO 14001 [1] and the European Regulation CE 761/01 "EMAS" [2].

The efficacy of an EMS can be improved also integrating it to other public initiatives for the sustainable development (as local Agenda XXI projects and the environmental accounting tools).

\section{The role of the park's Responsible Body}

The preservation of valuable natural subjects represents the main reason to the establishment of parks and reserves. The protected areas can also contain historical and artistic heritages or can involve standing or neighbouring build-up areas or productive plants. Depending on the dimensions, a park can involve a large and variable number of institutional subjects and public authorities. They cannot operate separately, but they have to state a common and synergic way to proceed and administrate the territory.

These elements make particularly complex the management of the park needing to meet the various social and economic interests of stakeholders.

For all these reasons is generally instituted a supervisor public body (the park's Responsible Body, successively named as RB) to manage the park [3]. The RB is generally directed by an administration council which includes political, scientific and technical staff.

The competences of the RB can include:

- planning activities to regulate the human activities and to control the evolution of natural habitats;

- design activities, including the protection of natural areas, the environmental recovery of degraded areas, the creation of new service structures;

- watch, to prevent and contrast environmental accidents and problems;

- repressive actions against outlaws activities;

- issue of new licences and authorisations;

- administrative actions, including management of the personnel;

- management of park's facilities, services and buildings;

- formation and information of citizens;

- scientific researches.

\subsection{Implementation of an EMS to the activities of a park's RB}

An EMS can support the management of a park, giving to the administration a structured, transparent and organised system to individuate, monitor and improve its significant environmental aspects. The implementation of an EMS becomes complex when it involves a large territory and a lot of different stakeholders (local authorities, towns or smaller settlements, industries, tourists, NGO, etc.). 
In particular, the activities of private subjects could influence sensibly the quality of the park's environment and could be responsible of significant impacts. The RB cannot directly attend and modify these private processes but can influence indirectly their behaviours by means of control actions and restrictions. The relationships with external subjects are the crucial point for the success of the entire system [4].

In order to achieve the protection of the environment it is necessary to create a positive and collaborative atmosphere among all the subjects that operate inside the park, avoiding conflicting relationship and planning common shared objectives. Every stakeholder can be actively involved in the park's management system and they could positively contribute to the environmental improvement by providing new data and information, sharing the environmental targets and moving in a proactive way towards such objectives.

The EMS works at two different levels:

- the inner improvement of the environmental management of the RB, that has to reduce its impacts and to control its activities;

- the external improvement of all the controlled territory, inducing also external actors to a more environmentally friendly behaviour.

The key points about the application of an EMS to natural parks are following summarised:

- The EMS has to be applied to the park's RB or an equivalent directive structure. This body can use EMAS logo;

- The environmental certification should involve all the activities carried out by the RB that can directly or indirectly impact on the managed territory;

- The RB has to carefully evaluate the sensible and vulnerable natural targets, evaluating the quality status of the habitats and ecosystems. The study should also include a socio-economic analysis regarding both the protected and the neighbouring areas in order to avoid that adjacent productive activities that could threaten the park with their environmental impacts;

- The improving actions shall focus on the RB's competences but should indirectly involve all the activities insisting into the park;

- Targets and aims have to refers to the entire protected territory;

- People that operate in the park have to modify their actions in order to accomplish with the park's guidelines;

- The RB can influence external subjects, i.e. by supporting and financing environmentally friendly activities, by fixing restrictions to companies that operated in the areas or granting special licenses and authorisations only to "green" companies;

- The RB can qualify the external subjects by means of an environmental park's logo that points out and awards the eco-compatible companies. It is however desirable that these subjects will successively join the EMAS certification themselves [5].

\subsection{EMS applied to Natural Parks: state of art}

Nowadays in Italy, the certifications of natural parks include 11 organisations certified by ISO 14001 [6] and 6 organisations certified by EMAS scheme [7]. 
We can observe a great incidence of EMAS registrations. In fact, this scheme grants visibility and large image benefits and, compared to the ISO scheme, it could be considered as more suitable for the certification of an extended territory.

In Europe, we assisted to a generalised delay in the EMAS certification of parks: only four parks have been certified, one in Denmark and Spain and other two in Germany [7].

The greater diffusion in Italy can be probably related to the Italian "Law on the protected areas" (law n ${ }^{\circ} 394 / 91$ ) that regulates the management of parks and set up the special competences, powers and responsibilities of RB. As requested by the law, the park's management has to accomplish to several planning activities (including the plans for the socio-economic development of he area) that partially satisfy to the EMAS requirement of management of indirect and planning aspects [8]. It is then advisable that in future such typology of laws would be strengthened and boosted.

However, the legislation generally does not prescribe the direct involvement of other external subjects. This could instead represent the added value related to the implementation of an EMS.

\section{Table 1: $\quad$ Environmental aspects.}

\begin{tabular}{|c|c|}
\hline $\begin{array}{l}\text { Environmental } \\
\text { aspects }\end{array}$ & Related improving environmental objectives \\
\hline \multirow[b]{2}{*}{$\begin{array}{l}\text { Effects on the } \\
\text { biodiversity }\end{array}$} & Maintenance and protection of the habitats \\
\hline & $\begin{array}{l}\text { Sustainable exploitation of the natural heritage; Location of great and old } \\
\text { trees; Increase of surfaces maintenance; Forestry; Study of the composition of } \\
\text { the floristic and faunal heritage (electronic databases); Protection of pasture } \\
\text { areas (delimitation and regulation); Protection of coastal and marine bands; } \\
\text { Reduction of the coastal erosion; Incentive to the substitution of old plants. }\end{array}$ \\
\hline \multirow{3}{*}{$\begin{array}{l}\text { Administrative } \\
\text { and planning } \\
\text { decisions }\end{array}$} & $\begin{array}{l}\text { Survey of concessions of the state demesne; Analysis of commercial and } \\
\text { productive activities/infrastructures in the territory; Monitoring of territory. }\end{array}$ \\
\hline & $\begin{array}{l}\text { Partnership of RB with other public authorities; Establishment of autonomous } \\
\text { systems of surveillance and vigilance; Keeping of registers (tourist presences, } \\
\text { sanctions, concessions, fauna); Regulation of sustainable tourism }\end{array}$ \\
\hline & Electronic cartography; Creation of Geographical Information System (GIS) \\
\hline $\begin{array}{l}\text { Risk of } \\
\text { environmental } \\
\text { accidents }\end{array}$ & $\begin{array}{l}\text { Fire and flood prevention plans; Maintenance of woods; Reduction of } \\
\text { hydrogeology risks; Shared procedures with Forest Bodies and Civil } \\
\text { Protection }\end{array}$ \\
\hline $\begin{array}{l}\text { Socio-economic } \\
\text { promotion }\end{array}$ & $\begin{array}{l}\text { Promotion of a Park quality mark; Certification of the local firms; } \\
\text { Consultation of local authorities and stakeholders to define shared initiatives. }\end{array}$ \\
\hline Mobility & $\begin{array}{l}\text { Sustainable mobility plans for the tourists and villagers; diffusion and } \\
\text { incentives to low-impacts transportations. }\end{array}$ \\
\hline $\begin{array}{l}\text { Diffusion of } \\
\text { environmental } \\
\text { information }\end{array}$ & $\begin{array}{l}\text { Environmental communication for tourists and residents; Organization of } \\
\text { events, publications, brochure, internet sites, videos, posters, etc.); } \\
\text { Establishment of information points; Creation of naturalistic paths; promotion } \\
\text { of environmental certifications and of the EMAS logo; }\end{array}$ \\
\hline $\begin{array}{l}\text { Waste } \\
\text { management }\end{array}$ & Waste recycling; Installation of "ecological islands" \\
\hline Waste water & $\begin{array}{l}\text { Analysis and monitoring of surface and deep water bodies; Purification of } \\
\text { waste waters with natural systems }\end{array}$ \\
\hline
\end{tabular}




\subsubsection{Environmental aspects, objectives and targets}

From the analysis of the Environmental Statements of registered parks [9-12], it has been selected a list of significant environmental aspects, objectives and targets. These data, summarised in Table 1, can represent a useful guideline for parks that would undertake the route to the environmental certification.

\section{Peculiarities and criticises in the implementation of an EMS}

The management of a large territory has peculiarities that differ from the normal management of a company. Besides the grant of services, the RB has specific planning responsibilities, granting the quality improvement of the environment and the conservation of natural resources. It is then necessary that the park's EMS would take into consideration all the environmental aspects of the territory, both caused by the direct park's management or by other external subjects [13]. The RB has to improve the efficacy and the efficiency of its planning and to control all the actions that can have an environmental influence on the territory.

It is desirable that the RB would implement an EMS to its management and, contemporary, would drive the private subjects to develop an own EMS. However, this approach is not easily practicable because some companies could perceive the certification as a compulsion and a restriction of their free enterprise. Table 2 describes the elements of the EMS and the criticisms related to the application to a natural park [14].

Stakeholders have the twofold role of controller and controlled: they, in fact, verify that the territory management would be eco-compatible and respectful of their necessities; on the other side, private subjects have to follows the park's recommendations and guidelines and to modify their activities in order to reduce their significant environmental impacts.

Being the EMS a voluntary tool, it is important that the improvement actions would be discussed and approved by all the interested subjects. Cooperation among stakeholders has to be activated just in the early stages of the certification, during the individuation of environmental significant aspects. Similarly to the Agenda 21 approach, the creation of forums and public meetings can assist the RB in the preliminary stage of certification [4]. These forums are not mandatory but they are desirable in order to share a common way to proceed and to avoid future contrasts and hostilities.

\section{Benefits and drawbacks}

A natural park can largely benefit about the implementation of a certified EMS. First of all, the data survey helps the organisation to acquire awareness of its activities and their repercussions on the environment as much as the vulnerable environmental elements of the territory.

Second, the EMS helps to systematically organise and control the park's competences and the decisional processes. The detailed IEA gives a figure of the effects and the consequences of park's action and planning activities. The EMS allows also to identify key roles and hot spots and to clearly assign the management responsibilities [15]. 
Table 2: $\quad$ EMAS requirements for EMS and related critical aspects.

\begin{tabular}{|c|c|}
\hline Requirement & Critical aspects \\
\hline $\begin{array}{l}\text { Environmental } \\
\text { Policy }\end{array}$ & $\begin{array}{l}\text { The Policy has to include two mandatory engagements: the legal compliance } \\
\text { and the undertaking to the continuous environmental improvement. The Policy } \\
\text { can then refer to future general engagements as: protection of habitats and } \\
\text { biodiversity, reduction of environmental impacts in the territory, sustainable } \\
\text { fruition of citizens and tourist. The park's RB ratifies this document without } \\
\text { necessarily involving citizens and external actors. }\end{array}$ \\
\hline $\begin{array}{l}\text { Environmental } \\
\text { aspects }\end{array}$ & $\begin{array}{l}\text { The EMAS regulation fixed that the company's top management would } \\
\text { individuate every direct and indirect activity that could produce significant } \\
\text { environmental impacts. The initial data acquiring process is summarised in a } \\
\text { document named Initial Environmental Analysis (IEA). Being the preservation } \\
\text { of natural habitats the main scope of park's administration, the collection of } \\
\text { update data and information about the status of the environment is an initial } \\
\text { prerogative as much as a future target. The environment monitoring reveals } \\
\text { itself as a critical matter, a more critical point compared to the registration } \\
\text { process competing to other private organisations. The IEA has to regards not } \\
\text { only the RB but all the activities insisting in the park and in the neighbouring } \\
\text { areas. The IEA aims to individuate: Natural characteristics (insisting flora, } \\
\text { fauna, geomorphology, hydrology, landscape, etc.); Sensible and vulnerable } \\
\text { targets; Activities and responsibilities of the RB; Productive and tourist } \\
\text { activities; Socio-economic status of the studied area. } \\
\text { It is import to underline that the control of indirect aspects is generally more } \\
\text { important and complex than the direct impact produced by the RB. During the } \\
\text { IEA it is possible to select significant environmental indicators and indexes } \\
\text { that allow a continuous monitoring of the environment, its time evolution and } \\
\text { the efficacy of undertaken improving actions. Aspects to take into account are: } \\
\text { air and water emissions; waste management; natural resource depletion; use of } \\
\text { the soil; use of chemicals; noise and vibrations; biodiversity; quality of natural } \\
\text { habitats and ecosystems; flora and fauna conservation; the monitoring and the } \\
\text { control of productive activities and urbanized areas. }\end{array}$ \\
\hline $\begin{array}{l}\text { Legal and other } \\
\text { requirements }\end{array}$ & $\begin{array}{l}\text { The EMS has to be centred to the respect of all the compulsory laws and } \\
\text { regulations: general government laws, regional and local directives, special } \\
\text { laws (as the special directives that set up the parks and define the competence } \\
\text { of the RB). It is suggested to develop procedures and instructions in order to } \\
\text { regularly update the register of official instructions and in order to control the } \\
\text { respect of deadlines. }\end{array}$ \\
\hline $\begin{array}{l}\text { Objectives, } \\
\text { targets and } \\
\text { environmental } \\
\text { programme }\end{array}$ & $\begin{array}{l}\text { The definition of targets is probably the most important and critical matter. It } \\
\text { applies not only on the inner activities of the RB, but also to activities of } \\
\text { external subjects operating in the controlled territory. } \\
\text { Objectives and targets have to be in accordance with the policy's statements. } \\
\text { The targets involve also the design and planning activities of the RB. It is } \\
\text { necessary that this stage would be responsibly carried out, evaluating in detail } \\
\text { the effects of planned actions and the spin-off on the territory. By means of } \\
\text { feasible and suitable plans the RB can control indirect environmental aspects } \\
\text { related to the citizens and private company's activities. The efficacy of plans is } \\
\text { also related to a strict control of the respect of the fixed requirements. } \\
\text { Objective and targets are summarised in the environmental programme that } \\
\text { includes a precise description of times, responsibilities and employed } \\
\text { resources. }\end{array}$ \\
\hline $\begin{array}{l}\text { Structures and } \\
\text { responsibilities }\end{array}$ & $\begin{array}{l}\text { The managerial structure of the park should clearly define competences of } \\
\text { managers and workers regarding their role and responsibilities in the EMS. } \\
\text { Furthermore, the RB should designate intermediary bodies for the } \\
\text { relationships with stakeholders to assist the RB during: data survey, location of } \\
\text { environmental criticises, definition of environmental programmes, } \\
\text { communications, monitoring and auditing activities. }\end{array}$ \\
\hline
\end{tabular}


Table 2: $\quad$ Continued.

\begin{tabular}{|c|c|}
\hline $\begin{array}{l}\text { Training, } \\
\text { awareness and } \\
\text { competence }\end{array}$ & $\begin{array}{l}\text { The park's management should foresee training courses on those subjects that } \\
\text { could influence the park's environmental management. First of all, the training } \\
\text { has to concern workers. They have to acquire awareness of the environmental } \\
\text { impacts related to their activities, the best practises and procedures to } \\
\text { minimise impacts and their competences. The training has to be yearly } \\
\text { updated, checked and documented. Contemporary, the RB has to improve the } \\
\text { environmental awareness of external subjects that live or operate in the park's } \\
\text { territory. They should be adequately informed and awaken about their role in } \\
\text { the EMS. }\end{array}$ \\
\hline Communication & $\begin{array}{l}\text { The RB shall foresee apposite procedure to control of communications } \\
\text { addressed to internal (workers, persons in charge, contracting firms) and } \\
\text { external subjects (public authorities, private companies, citizens). } \\
\text { Communication can regard: modifies of park's policy and programmes, new } \\
\text { laws and regulations, environmental criticises, internal and external } \\
\text { procedures, publication of data and environmental statements, emergencies, } \\
\text { etc. The communication channels are also useful to acquire information from } \\
\text { external subjects as: data, improvement suggestions, complaints and problems. }\end{array}$ \\
\hline Document control & $\begin{array}{l}\text { The control applies to internal and external documents. It aims to grant that all } \\
\text { the significant records would be correctly renewed, stored and available where } \\
\text { necessary. Due to the large number of documents and in order to increase the } \\
\text { efficiency of the control, the park's RB should computerise this process. }\end{array}$ \\
\hline $\begin{array}{l}\text { Operational } \\
\text { control }\end{array}$ & $\begin{array}{l}\text { The operational control regards the monitoring of the environment quality by } \\
\text { means of Environmental Condition Indicators (ECI) about the entire territory, } \\
\text { and by means of Performance Indicators (PI) concerning the management of } \\
\text { the park and of the other private companies operating in the territory. This } \\
\text { phase is carried out by means of suitable procedures and responsibilities in } \\
\text { order to control all the significant environmental aspects identified during the } \\
\text { IEA } \\
\text { The EMAS regulation also foresees that the organisation would fix and } \\
\text { periodically update procedures for the selection of suppliers and contractors. } \\
\text { These subjects should be qualified on the basis of environmental criteria and } \\
\text { requisites fixed in collaboration with all the stakeholders. }\end{array}$ \\
\hline $\begin{array}{l}\text { Emergency } \\
\text { preparedness and } \\
\text { response }\end{array}$ & $\begin{array}{l}\text { The RB has to locate possible states of emergency. They include natural } \\
\text { accidents (as fire, flood, earthquake, etc.) as much as anomalies of the normal } \\
\text { activities. Emergences belonging to the first type have to be faces thanks to a } \\
\text { detailed analysis of the territory, with a constantly update data acquiring } \\
\text { system; to face emergences of the second type it is necessary the collaboration } \\
\text { of private subjects operating in the territory, in order to avoid environmental } \\
\text { problems due, for example, to accidental releases of toxic substances or the } \\
\text { halt of purification plants. Each emergency has to be monitored and apposite } \\
\text { procedures are required to face the emergency and to alert citizens and other } \\
\text { involved subjects. }\end{array}$ \\
\hline $\begin{array}{l}\text { Monitoring and } \\
\text { measurement }\end{array}$ & $\begin{array}{l}\text { This phase aims to acquire data useful to the selection of significant } \\
\text { environmental aspects, to control the evolution of habitats and to the } \\
\text { accomplishment of targets and objectives. }\end{array}$ \\
\hline $\begin{array}{l}\text { Non-conformance } \\
\text { and corrective } \\
\text { and preventive } \\
\text { action }\end{array}$ & $\begin{array}{l}\text { Nonconformances represent anomalous situations detected during audits and } \\
\text { monitoring. Nonconformances require immediate actions, in order to prevent } \\
\text { accidents or serious environmental problems. The RB should also undertake } \\
\text { initiatives in order to prevent nonconformances. }\end{array}$ \\
\hline Records & $\begin{array}{l}\text { All the significant activities have to be recorded in order to grant an adequate } \\
\text { evidence of the park's data and activities. }\end{array}$ \\
\hline
\end{tabular}


Table 2: $\quad$ Continued.

\begin{tabular}{|l|l|}
\hline $\begin{array}{l}\text { Environmental } \\
\text { management } \\
\text { system audit }\end{array}$ & $\begin{array}{l}\text { During this phase, the EMS is checked in order to locate the non- } \\
\text { conformances. The audits are also important to locate strong and weak point of } \\
\text { the systems and the sectors with the higher improvement margins. External } \\
\text { accredited verifiers control the activities of the RB. The park's management } \\
\text { has also to plan internal audits in order to check its internal activities as much } \\
\text { as the behaviour of other subjects operating in the territory. }\end{array}$ \\
\hline $\begin{array}{l}\text { Management } \\
\text { review }\end{array}$ & $\begin{array}{l}\text { This phase is carried out by the park's management. It is required a detailed } \\
\text { review of all the previous steps and, in particular, of nonconformances in order } \\
\text { to verify the adequacy and efficacy of corrective actions. }\end{array}$ \\
\hline
\end{tabular}

Other benefits related to environmental certification are:

- to improve the environmental efficiency (reduction of consumption of energy and natural resources, improvement of the environment quality, employment of plants and products with lower environmental impacts, diffusion of environmental information, realisation of actions for the environment recovery);

- to accomplish with the laws in force and the deadlines;

- to assign organically authorisations and concessions to private companies, in order to globally minimise environmental impacts;

- to monitor the quality and the evolution of natural habitats;

- to control the accomplishment of the environmental programme and the efficacy of environmental actions and plans;

- to set environmental indexes and indicators (useful to study, compare and communicate the park's performances);

- to improve the park's image [4].

The RB will also improve its credibility, giving to citizens and other organisations a transparent figure of the park's management. In this way, the undertaken actions and the imposed restrictions will be more easily accepted. In particular, the publication of the Environmental Statement increases the visibility of the park, showing the engagement for the environment and the obtained results.

The involvement of other stakeholders, such as public authorities and companies, allows one to avoid conflictual relationships among private and public subjects. The development of shared action programmes and planning make possible to companies to perceive the park's EMS as an added value for the territory. The certification could have a spin-off effect on the companies that could so link their name and production to the environmental quality of the territory [16].

Firms could then have economic benefits due to: resources saving, the improvement of waste management, the purchasing of sensible clients that will reward their ecological productions.

\section{Conclusions}

The management of a natural park includes a lot of different and difficult activities. The development of an EMS in accordance with the international 
standards (EMAS, ISO14001) allows one to organically and systematically manage and control all these activities. In particular, the added value of the EMS is related to the detailed selection of environmental criticises and the clear definition of rules and responsibilities within the park. The development of an internal monitoring system allows one to control the evolution of environmental performances and the efficacy and efficiency of undertaken corrective actions and the accomplishment of environmental targets and objectives.

Finally the publication of the Environmental Statement grants the transparency of park's activities and improves the relationships with citizens, NGO, public authorities and other stakeholders.

The main difficulties of the certification process are related to the role of private subjects that the park's management cannot directly control. It is then necessary to involve these actors just during the planning activities, in order to define shared objectives and procedures.

Benefits are both environmental (due to the correct management of significant environmental aspects) and economic (due to the optimisation of resource use). All the territory could benefit of an image improvement with a spin-off effect to the tourist activities in the area and the promotion of local productions.

\section{References}

[1] International Standard ISO 14001 "Environmental Management systems — Requirements with guidance for use". Second edition 2004.

[2] Regulation (EC) No 761/2001 of the European Parliament and of the Council allowing voluntary participation by organizations in a Community eco-management and audit scheme (EMAS).

[3] Province of Turin, WWF Piemonte. "Implementation of EMS to Protected Areas - Guidelines for the application of ISO 14001 to the Provincial Park of the Lake of Candia -. Turin. (In Italian).

[4] Naviglio L., Adamoli R., Bruzzesi F., Castorina M., Minciardi M. R., Morgana J. G., Rossi G., Paci S. "The EMS as a tool for the promotion and the development in the parks and reserves", ENEA, Second National Conference of Natural Protected Areas, 11-13 October 2002 Turin. (In Italian).

[5] Molinas P. -“EMAS registration of "Territory”: The sample of Parks and natural reserves” - Agenzia per la Protezione dell'Ambiente e per i Servizi Tecnici (APAT), Ambiente e Sviluppo 2002. (In Italian).

[6] SINCERT website www.sincert.it.

[7] European register of EMAS website www.europa.eu/emas.

[8] Italian Law 6.12.1991 n. 394 "Legge quadro sulle Aree Protette".

[9] Environmental Statement 2004 -Protected Marine Area "Tavolara - Punta Coda Cavallo"- Olbia (SS) Italy. (In Italian).

[10] Environmental Statement 2003 "National Park of Dolomiti Bellunesi"Feltre (BL) Italy. (In Italian).

[11] Environmental Statement 2004 -Protected Marine Area and Natural Reserve "Torre Guaceto"- Brindisi, Italy. (In Italian). 
[12] Environmental Statement 2003 -Natural Park of Monte AvicChampdepraz (AO) Italy. (In Italian).

[13] ENEA-SINCERT-“Application of ISO 14001 in the protected areas", Environmental management: Guideline 1, Milan 1-109. (In Italian).

[14] Paci S., Naviglio L. "The problem of application of an Environmental Management System in protected natural areas. ENEA October 2000 (In Italian).

[15] Naviglio L. "The certification in parks and natural reserves". Valutazione Ambientale n. 4, December 2003. (In Italian).

[16] Naviglio L. ENEA "Parks in quality: The Environmental Management System in protected areas”. Parco Produce 2001- 24 November 2001 Ancona, Italy. (In Italian). 